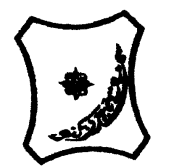

Bayero Journal of Pure and Applied Sciences, 9(1): 160 - 165

Received: November, 2015

Accepted: April, 2016

ISSN $2006-6996$

\title{
THE EFFECT OF PLANT GROWTH REGULATORS ON CALLUS INITIATION IN WORMWOOD (Artemisia annua L.)
}

\author{
Tahir, S.M. ${ }^{1}$, Usman, I. S., ${ }^{2}$ Katung, M.D. ${ }^{2}$ and Ishiyaku, M. F. ${ }^{2}$ \\ ${ }^{1}$ Department of Biological Sciences, Kaduna State University, Kaduna. \\ ${ }^{2}$ Plant Science Department, Ahmadu Bello University, Zaria. \\ Corresponding author: stahir1990@gmail.com or smtahir@kasu.edu.ng
}

\begin{abstract}
Studies were carried out in the Biotechnology laboratory of Plant Science Department of Ahmadu Bello University Zaria, Nigeria to study the effect of some plant growth regulators on the in vitro initiation of callus using the leaves of Chiyong variety of Artemisia annua. The explants were sterilized and incubated on Murashige and Skoog basal media augmented with varying concentrations ranging from 0.5 to $3.0 \mu \mathrm{m} / \mathrm{l}$ of Giberellic acid (GA3), Benzyle amino purine (BAP), Naphthyle acetic acid (NAA),2,4-Dichlrophynoxyacetic acid (2,4-D), Indole butyricacid (IBA) and Kinetin (Kin). The experiment was arranged in a completely randomized design with 2 replicates. Low BAP concentration of $0.5 \mu \mathrm{m} / \mathrm{I}$ and a high concentration of NAA of $3.0 \mu \mathrm{m} / \mathrm{I}$ as well as equal concentration of BAP of $1.0 \mu \mathrm{m} / \mathrm{l}$ and IBA of $1.0 \mu \mathrm{m} / \mathrm{l}$ had the least days (7days) to regeneration. For regeneration percent, equal low concentrations of BAP of $0.5 \mu \mathrm{m} / \mathrm{I}$ and $\mathrm{NAA}$ of $0.5 \mu \mathrm{m} / \mathrm{I}$ had the highest performance of $94 \%$. However, no significant difference was observed between treatments with respect to vigor. Equal low concentrations of $B A P(0.5 \mu \mathrm{m} / I)$ and $(0.5 \mu \mathrm{m} / \mathrm{I}) \mathrm{NAA}$ and $B A P(1.0$ $\mu \mathrm{m} / \mathrm{I})$ combined with IBA(1.5 $\mu \mathrm{m} / \mathrm{I})$ had the highest height. Results of Analysis of Variance (ANOVA) indicated significant difference among the treatments compared with the control $(P<0.05)$. Therefore, combined BAP and NAA treatment is an efficient protocol for callus initiation and proliferation. A combination of GA3 and BAP is suitable for shoot initiation from callus using cultures of A. annua.
\end{abstract}

Keywords: Artemisia annua, in vitro, Nodal cuttings, growth regulators

\section{INTRODUCTION}

Artemisia annua L (Wormwood) belongs to the family Asteraceae (Compositae). Ferreira, and Janick (2002) and consist of about 400 species $(2 n=36)$ (Bailey and Bailey, 1976; Bennett et al., 1982; El-haq et al., 1991; Jaime and Da silver, 2003; Klayman, 1993; McVaugh, 1984). The family is characterized by extreme bitterness of all parts of the plant (Tripathi et al., 2000; Tripathi et al., 2001; Ferreira and Janick, 2009).

$A$. annua is a determinate short-day plant very responsive to photoperiodic stimulus. The critical photoperiod is about 13.5 hours. It thrives in many temperate to sub-tropical ecologies. Its cultivation spread from China to Africa, mainly Kenya, Tanzania and Nigeria in response to the call by the World Health Organization for the use of ArtemisininCombination Therapies (ACT). The most concentrated areas of artemisia production are Asia, Europe, and USA and recently East Africa (Klayman, 1993). However, global estimates for $A$. annua revealed a production rate of 2,000 ha in 2003, 3000 ha in 2004, 9,500 ha in 2005, 26.000 ha in 2006, 14,500 ha in 2007, 4,500-5,000 ha in 2008, and 6,000 ha in 2009 (Pilloy, 2010; RBM, 2009). In China production rate of 2,000 ha in 2004, 600 ha in 2005 and 9,000 ha in 2006 of Artemisia were reported. Related biomass volumes were placed at $3,000,10,000$, and 14,000 tons respectively (Tan, 2006). Vietnam was also a substantial producer but the area is reported to have dropped from 10,000 ha in 2006 to 3,000 ha in 2007, 1,000 ha in 2008, 700 in 2009, 500-700 in 2010, and then expanded to 1,500 ha in 2011 (Cutler, 2008; Artepal, 2008; Hiey, 2010; Ut, 2011). India has the potential for Artemisia cultivation but no estimates of production have been identified (Sharma, 2006; Cutler, 2008).

In 2005, Kenya, Uganda, and Tanzania recorded an annual production of 1,650 ha each. The yield raised in 2007 to 3,500 and 4,000 ha respectively (ABE, 2007). In Nigeria, propagation of $A$. annua started in 2003 while artemisinin extraction commenced in 2005. As of August 2007, over 1,500 ha was prepared for planting with seeds from Brazil, China and local breeds. (Anonymous, 2007; NA, 2007).

Propagation problems include shortage of seed/ seedlings, lack of sufficient training, difficulty to meet quality standards for processing and extraction, steady market and profitable price to attract farmers, weed control, harvesting and drying techniques (ABE, 2006).

East Africa was placed at about 4,000 ha in 2006 and 2007 with an average biomass yields of 2.5 t/ha (EABL, 2005). Similar estimates were not available for other countries and areas (Cutler, 2008). 
Artemisia annua has been used in the treatment of skin diseases and it has also been shown to be an effective non-selective herbicide (Duke et al., 1987; Paniego and Giulietti, 1994). The anti-bacterial and antioxidant properties of the plant's extracts and essential oil are a welcome development in the livestock industry (Allen et al., 1997; Arab et al., 2006; Brisibei et al., 2008; Xiao and Catto, 1989; Xiao et al., 2000; Lescano et al., 2004). The plant has also been used to impair the growth and development of insects that attack stored grains ( Tripathi et al., 2000; Tripathi,2001). Three common derivatives found in Artemisia include artesunate, artemether and Artemisinin (Duke et al., 1987; Kinscher, 1992)

This study was carried out to establish a suitable micropropagation protocol for initiation of high yielding calli using $A$. annua leaf primordial.

\section{MATERIALS AND METHODS \\ Study Area}

The experiment was conducted in the Biotechnology Laboratory of Plant Science Department, Ahmadu Bello University, Zaria, latitude $11^{\circ} 11 \mathrm{~N}$ and $07^{\circ} 38$ $\mathrm{E}$, altitude $670 \mathrm{~m}$ above sea level, $640 \mathrm{~km}$ from the Atlantic shores of Nigeria in the south.

\section{Materials}

Leaf primordial of Chinyong variety of $A$. annua were sourced, sterilized and inoculated for callus initiation on a Murashige and Skoog basal media supplemented by varying concentrations of auxins using the procedure of Hamish and Sue (1998) and Razdan (2002).

\section{Treatments and experimental design}

Explants were subjected to the following treatments (Table I) and arranged in a completely randomized design with 2 replicates.

Table1: Combination of PGRs used as supplements together with MS medium for callus initiation in A. annua.

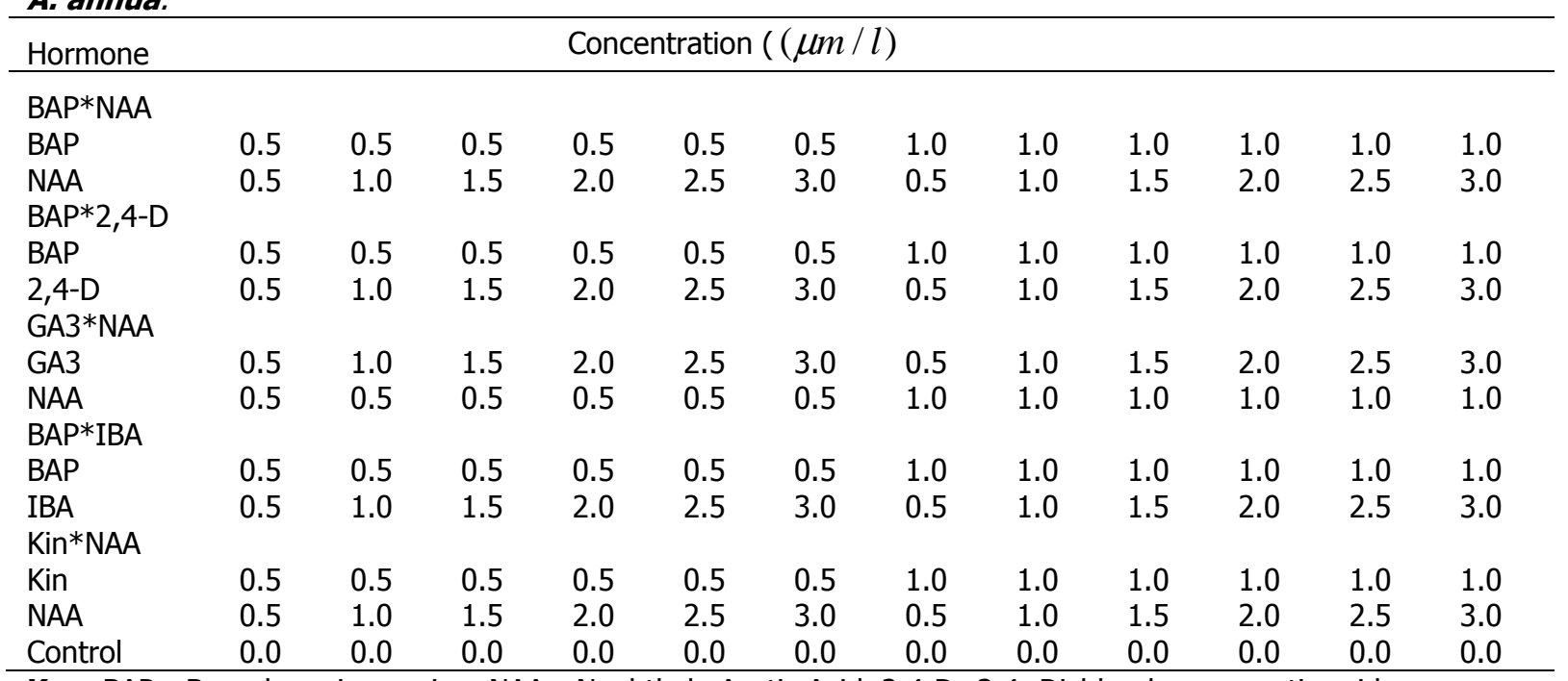

Key: $B A P=$ Benzyle amino purine. $N A A=$ Nephthyle Acetic Acid. 2,4-D=2,4- Dichlrophynoxyacetic acid. $\mathrm{GA} 3=$ Giberellic acid.IBA =Indolebutyric acid. Kin=Kinetin

\section{Sterilization.}

i. Surface sterilized in $90 \%$ ethanol for 5 minutes

ii. Ethanol solution was decanted and the explants were rinsed in autoclaved sterile water.

iii. This was followed by disinfection with $1 \%$ Mercuric Chloride $(\mathrm{HgCl})$ for 4 minutes.

iv. Explants were then rinsed $5 x$ in sterile distilled water before inoculation on the media.

\section{Inoculation}

Fresh and healthy leaf primordial explants (16$150 \mathrm{~mm}$ ) were sterilized and inoculated on a Murashige and Skoog (1962) basal media supplemented with varying concentrations of growth hormones using the procedure of Hamish and Sue (1998) and Razdan (2002). Callus was induced by transferring a $1 \mathrm{~cm}$ long piece of explants using a sterilized forceps onto a solid MS medium. The explants were inoculated aseptically in the culture room and were maintained at $24 \pm 1^{\circ} \mathrm{C}$ using $14 / 10$ light/dark period, under a light intensity of 3000 lux provided by cool-white fluorescent lamps and 50 to $60 \%$ relative humidity. The callus formed was sub cultured by transferring a small piece to a fresh medium until the callus became soft and fragile.

\section{Parameters Studied}

The following parameters were studied such as:
i. Days to callus initiation.
No of Days to initiation per leaf Total No of calli 
ii. \% Regeneration was calculated according to Wiese and Binning (1987)

$$
\text { i.e. } \% G r=\frac{n-1}{n}
$$

Where $\mathrm{Gr}=$ number callus initiation and $\mathrm{n}=$ the days of incubation.

iii. Callus vigor was determined based on morphological appearance, callus initiation and percentage initiation as described by Gibson (1980). A scale of 1 - 5 was used where $1=$ very high vigor and $5=$ very low vigor.

iv. Callus diameter was determined by spreading a thread against the length of a callus in the test tube after which it was placed on a measuring tape to measure its height in centimeter $(\mathrm{cm})$.

\section{Data Analysis}

The data was analyzed using Analysis of Variance (ANOVA), SAS (2002) statistical package. Means were separated by DMRT value at a $0.5 \%$ probability level.

\section{RESULTS}

Leaf primordial consist of Juvenile leaves that has higher population of actively dividing cells therefore might be responsive to callus initiation. One week after inoculation, explants swelled before callus initiation commenced from the cut edges. Callus appeared yellowish, compact, friable and nodular
(Plate I a and b). Series of changes occurred after callus initiation ranging from metabolic and morphological. Callus proliferation occurred after callus tissue was sub cultured. (Plate I b) Callus turned greenish after it has been transferred into the multiplication media and morphogenesis by way of shoot formation also commenced (Plate ii). Colour, friability and quantity of callus obtained from different treatments varied. Browning of some calli was also observed after subculture. Numerical assessment (15) was used for grading the vigor with 1 being the best.

Results of Analysis of Variance had indicated that a low BAP concentration $(0.5 \mu \mathrm{m} / \mathrm{l})$ and a high concentration of NAA $(3.0 \mu \mathrm{m} / \mathrm{l})$ as well as equal concentration of BAP $(1.0 \mu \mathrm{m} / \mathrm{I})$ and IBA $(1.0 \mu \mathrm{m} / \mathrm{l})$ had the least days to callus initiation. (Fig.1)

For regeneration percent, equal low concentrations of BAP $(0.5 \mu \mathrm{m} / \mathrm{l})$ and NAA $(0.5 \mu \mathrm{m} / \mathrm{l})$ had the highest performance $(94 \%)$. It was followed by $44 \%$ each using GA3 $(1.0 \mu \mathrm{m} / \mathrm{l})$ and NAA $(1.0 \mu \mathrm{m} / \mathrm{l})$ and low concentrations $(0.5 \mu \mathrm{m} / \mathrm{l})$ of BAP and $(1.0 \mu \mathrm{m} / \mathrm{l})$ IBA (Fig.2).

However, no significant difference was observed between treatments with respect to vigor (Fig.3) Equal low concentrations of $\operatorname{BAP}(0.5 \mu \mathrm{m} / \mathrm{l})$ and $(0.5$ $\mu \mathrm{m} / \mathrm{l}) \mathrm{NAA}$ and BAP $(1.0 \mu \mathrm{m} / \mathrm{l})$ combined with IBA $(1.5 \mu \mathrm{m} / \mathrm{l})$ had the best size in diameter. (Fig.4).

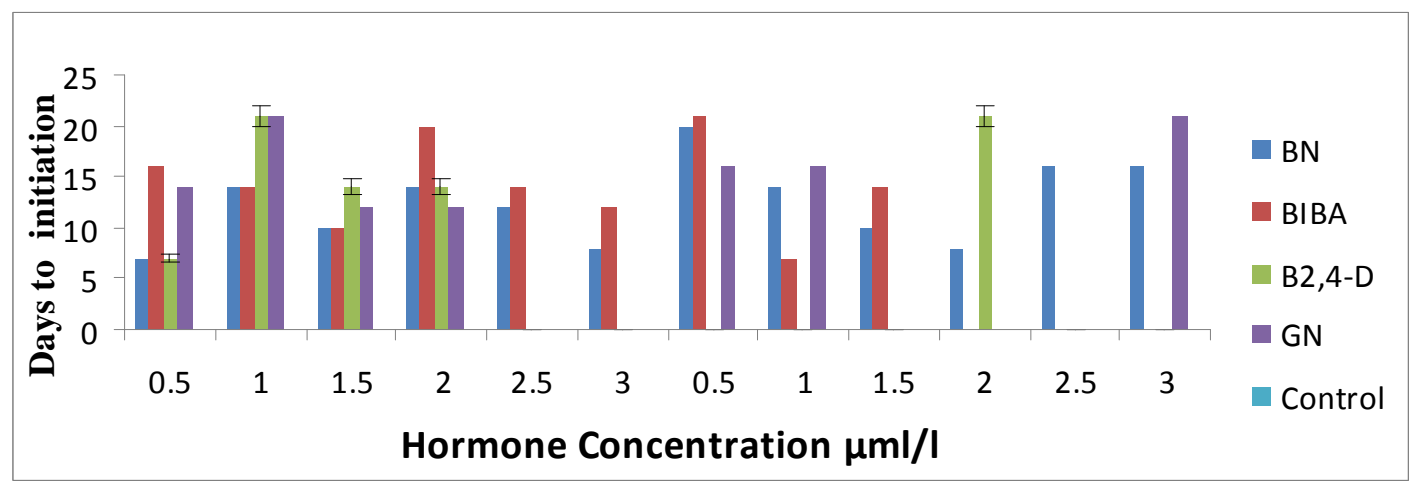

Figure 1. Effects of varying hormone concentration on days to callus initiation

Key: $\mathrm{BN}=$ Benzyle amino purine $*$ Naphthyle Acetic Acid. BIBA $=$ Benzyle amino purine * Indolebutyric acid . B2,4-D= Benzyle aminoPurine *2,4-Dichlrophynoxyacetic acid. GN= Giberellic acid * Naphthyle Acetic Acid .

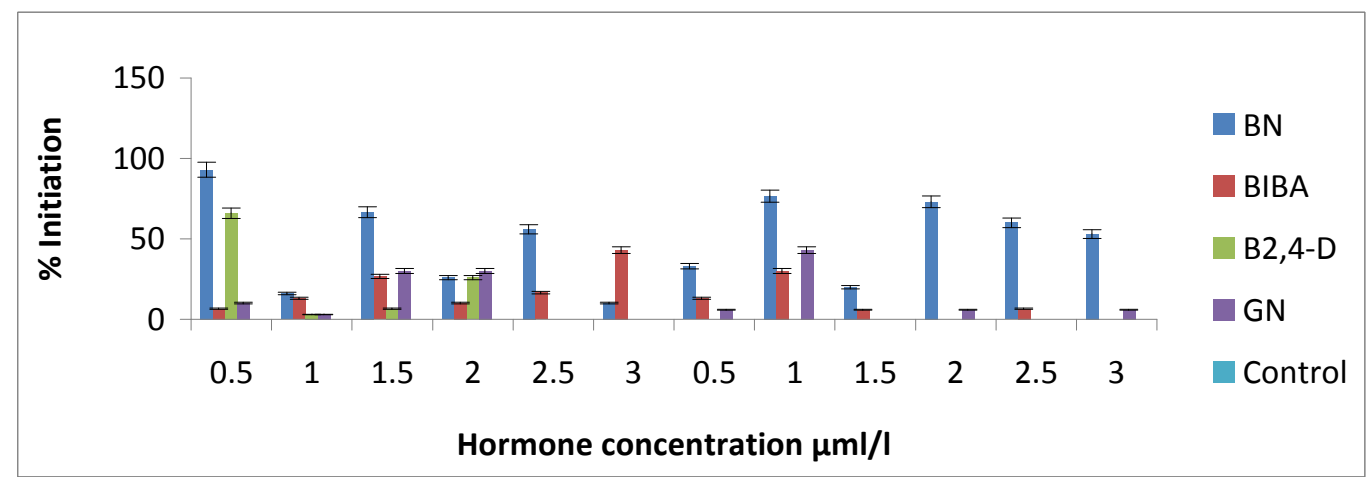

Figure 2. Effects of varying hormone concentration on callus regeneration percent

Key: $\mathrm{BN}=$ Benzyle amino purine $*$ Naphthyle Acetic Acid. BIBA $=$ Benzyle amino purine * Indolebutyric acid . B2,4-D= Benzyle aminoPurine *2,4-Dichlrophynoxyacetic acid. GN= Giberellic acid * Naphthyle Acetic Acid . 


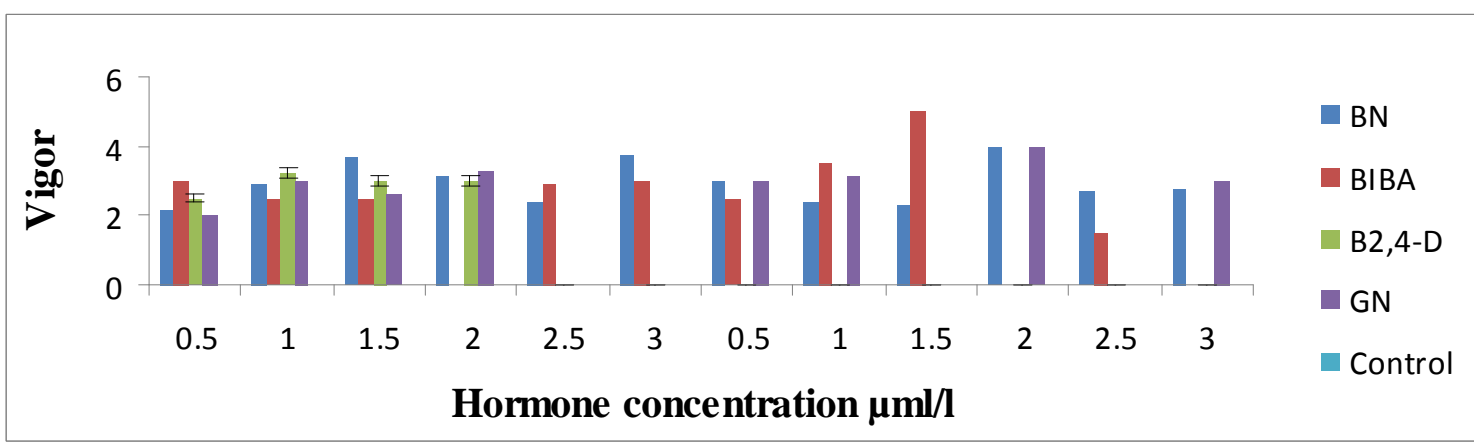

Figure 3. Effects of varying hormone concentration on callus vigor.

Key: $\mathrm{BN}=$ Benzyle amino purine * Naphthyle Acetic Acid. BIBA $=$ Benzyle amino purine * Indolebutyric acid . B2,4-D= Benzyle aminoPurine *2,4-Dichlrophynoxyacetic acid. GN= Giberellic acid * Naphthyle Acetic Acid .

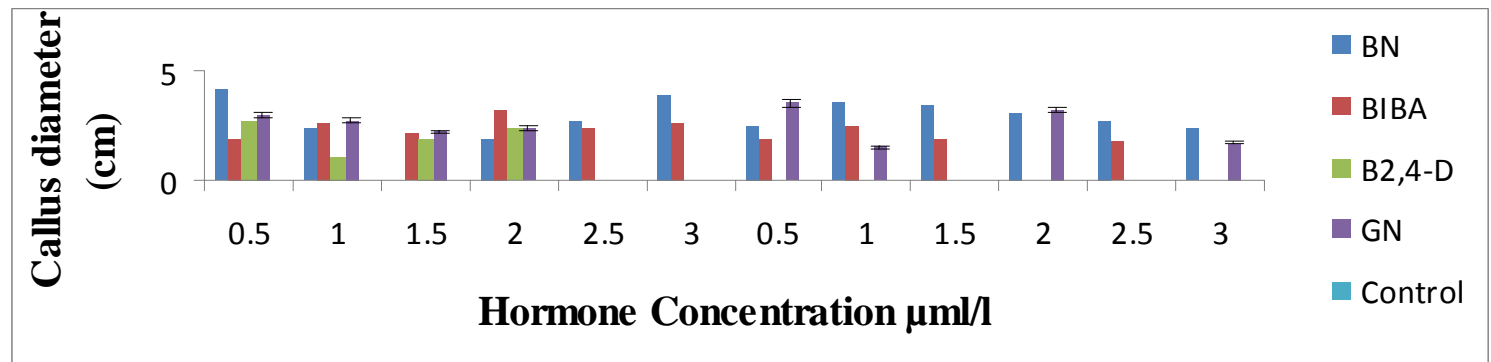

Figure 4. Effects of varying hormone concentration on callus length.

Key: BN= Benzyle amino purine $*$ Naphthyle Acetic Acid. BIBA $=$ Benzyle amino purine $*$, Indolebutyric acid . B2,4-D= Benzyle aminoPurine *2,4-Dichlrophynoxyacetic acid. GN= Giberellic acid * Naphthyle Acetic Acid .

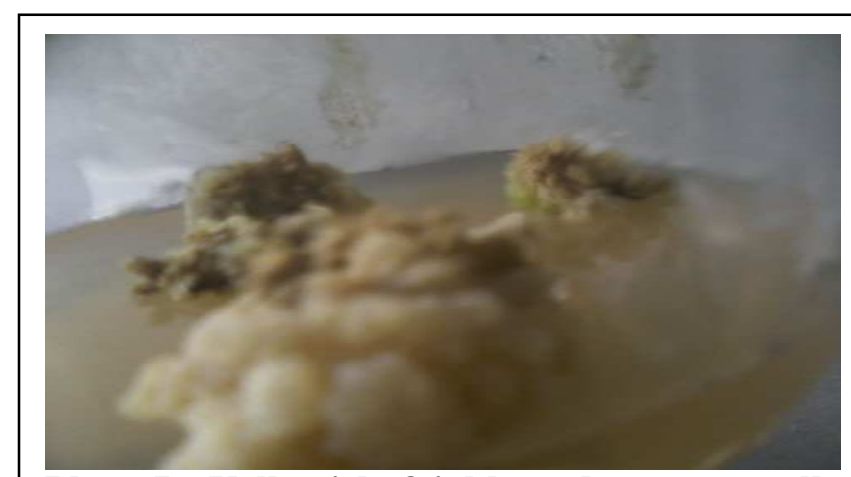

Plate. I a.Yellowish, friable and compact callus in diameter.

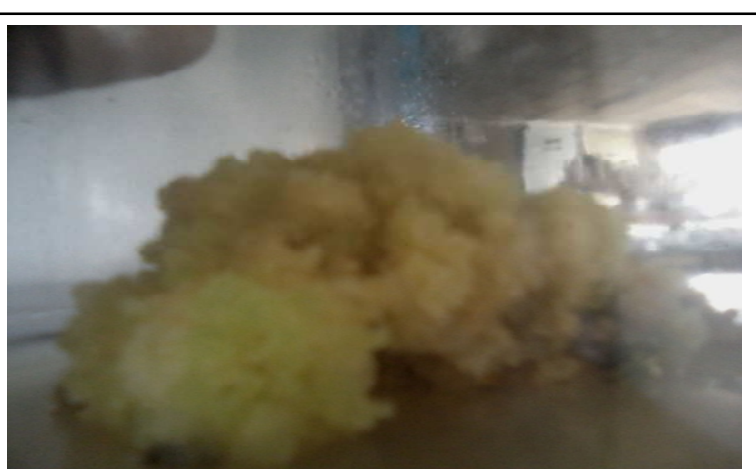

b. Amplification of callus brings increase

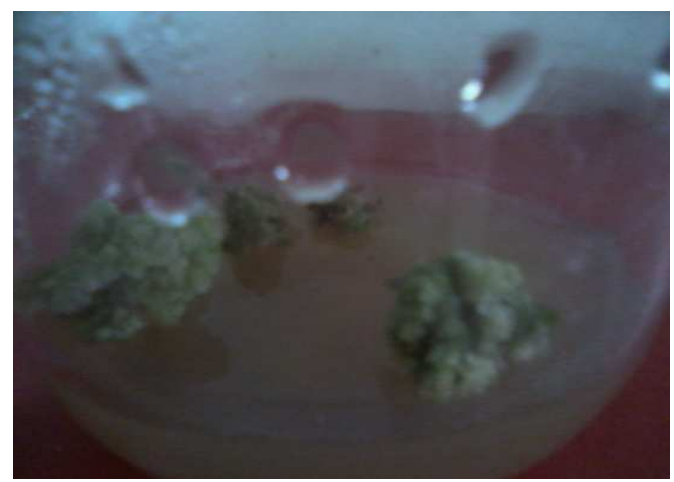

b.

.

Plate II a.

Subcultured calli undergoing differentiation marking the beginning of shoot formaton. 


\section{DISCUSSION}

Callus production is a process of dedifferentiation of organized tissue as indicated by changes in morphology and metabolic activity. Callus can be initiated from explants of almost any part of the original plant such as leaves, roots, and stems etc. Callus can be induced either by injury or by the addition of growth regulators - usually a proper ratio of auxin and cytokinin (Sugimoto et al., 2011). When a surface is cut, the cells at the wound site undergo division. With the first division being synchronous after 4-6 weeks of culture and continuous cell division, the explants tissue may have produced double its original weight in callus tissue (Hamish and Sue 1998; Razdan 2002). After initiation is the maintenance or proliferation of the callus material. This provides a source of uniform cells for a variety of purposes such as regeneration.

Juvenile leaves contain higher population of actively dividing cells therefore more responsive to callus initiation. The parent plant must be healthy and actively growing therefore, not about to enter period of dormancy (Razdan 2002, Hamish and Sue 1998).

Swelling of the explants was observed one week after inoculation. However, callus initiation was observed after the second week. Yellowish, compact and nodular callus at cut age of the explants may be due to the wound caused during the process of cutting which resulted in a synchronous cell division. This is considered as a process of dedifferentiation of organized tissue and its similar to the work of Hamish and Sue (1998). An embryonic callus possesses high regenerative capacity compared to those derived from mature organs such as leaf, stem and root.

This is true of conifers, cereals etc. The most serious draw back in the use of callus cultures for shoot multiplication is the genetic instability of their cells due to which initial plant regeneration capacity of the tissue may decline with passage of time (Razdan 2002) Manipulation of the media components may reverse de-differentiated process and the tissue redifferentiated back to an organized form (Hamish and Sue 1998) Control of differentiation was found to be dependent upon the presence of auxin and cytokinin. The physiological state of the tissue provided actively

\section{REFERENCES}

Advanced Bio-Extracts (ABE).(2006): "The Accelerated Production of Artemisinin in East Africa, Project Summary,"Advanced Bio-Extracts Ltd." Nairobi, Kenya

Advanced Bio-Extracts (ABE) (2007). "Project Status Report," Advanced Bio-Extracts Limited, Nairobi, Kenya.

Allen, P.P., Lydon, J. and Danforth, H.D. (1997): Effects of componenets of Artemisia annua on coccidian Infections in Chikens. Poultry Science. 76:1156-1163.

Anonymous (2007): "Nigeria set to Produce Drugs for Malaria," Daily Champion, Lagos.

Arab, H.A., Rahbari, S., Rassouli. A., Moslemi,M.H. and Khosravirad, F. (2006). Determinations of Artemisinin in Artemisia sieberi and Anticoccidial Effects of the Plant Extract in dividing cells and has an influence on the plant's response to the tissue culture program (Hamish and Sue1998, Brisibe et al.; 2008).

Muhammad et al., (2007) reported that Cytokinins and Auxins were found to be effective in callus culture of $A$ annua. At very low level (0.01m 1-1) GA promotes embryogenesis in young barley and an optimum callus induction with increase in 2,4-D concentration. Callus initiation is probably dependent upon genotype, medium and the explant used (Paniego and Giulietti, 1994) and it is accompanied by series of changes in both the appearance and metabolism of the cells (Hamish and Sue,1998).

Variations in colour and friability may be gene dependent. However, browning of callus after sub culture may be due to unstable medium (Razdan 2002, Hamish and Sue 1998).

Root and shoot formation from undifferentiated callus of tobacco was dependent upon the balance of Auxin and cytokinins. However, initiated calli undergo differentiation when they were transferred to bright light (Brisibe et al 2008). This probably triggers chlorophyll formation, hence commencement of photosynthesis. This eventually led to organogenesis. Differentiation of plant from cultured cells via somatic embryogenesis is a fast method of shoot multiplication and cloning of plant species (Razdan 2002; Sugimoto et al., 2011).

\section{CONCLUSION}

Results obtained from this study provides strong evidence that $0.5 \mu \mathrm{m} / \mathrm{l}$ BAP and $0.5 \mu \mathrm{m} / \mathrm{l}$ NAA combination is an ideal protocol for callus initiation in $A$ annua using leaf primordial explants. It is therefore suitable for mass production and multiple shoot regeneration.

\section{Acknowledgements}

The authors are grateful to the Biotechnology Program Unit of Institute for Agricultural Research (IAR), Dr I S Usman, the Head of Plant Science Department, Ahmadu Bello University, Zaria and Mal Suleiman Umar the Chief technologist of the Biotechnology laboratory, and his supporting staff for permission to use the lab facilities and their assistance towards making this work a success.

Broiler Chikens.Tropical Animal Health and Production. 38:497-503.

Artepal. Artemisinin market situation in June (2008). Artepal Newsletter [info@artepal.org],Aug. 12 update.

Bailey, L.H. and Bailey, E.Z. (1976): Hortus third. MacMillan Publ. Co., New York.

Bennett, M.D., J.B. Smith, and Heslop-Harrison, J.S.(1982). Nuclear DNA Amounts in Angiosperms. Proc. Royal Soc. London $B$ 216:179-199.

Brisibei E.R., Umoreu, U.E.,Owai, P.U and Brisibe, F. (2008). Dietery Inclusion of Dried Artemisia annua Leaves for Management of Coccidiosis and Growth Enhancement in Chikens. African Journal of Biotechnology 7:4083-4092. 
Cutler, Malcolm. "Artemisia/Artemisinin Industry Observations," unpublished paper, July,2008.

Duke S.O., Vaughn, K.C., Croom, E.M.J. and Elsohly, H.N. (1987) :Artemisinin, a Constituent of wormwood (Artemisia annua) is a Selective Phytotoxin. Weed Science 35:499-505.

East African Botanicals Ltd (EABL).(2005). Growers' Production Manual for Artemisia annua.

Elhag, F., EI-Feraly, J.S., and Hafez, M. (1991). In Vitro Propagation of Artemisia annua L. Journal of King Saud University. Agricultural Sciences.3 (2):251-2259.

Fatimah, B.M. (2003). An introduction to Biostatistics. Samarib Publishers, Kano, Nigeria..Pp19-20.

Ferreira J.F.S., J. Janick (2002). Production of Artemisinin from In vitro Cultures of Artemisia annua L., Biotechnology in Agriculture and Forestry Vol. 51, Springer-Verlag, Berlin, Germany.Pp. 1-12

Ferreira, J. and Janick, J. (2009). Annual Wormwood (Artemisia annua L.) WWW.hort.purdue. Edu/newcrop/crop fact sheets/Artemisia.

Gibson, M.S.(1980). Measurement of Vigor in Seeds or Seedlings. Sugarbeet Research and Extension Reports, 11,143-147.

Hamish A.C. and Sue, E. (1998). Plant Science Culture. BIOS Scientific Publishers limited. Oxford, London.Pp157.

Hiey, H.N. (2010). Artemisinin Vietnam. Artemisinin Conference, Madagascar, October

[www.mmv.org/newsroom/events/pastevents/ pastartemisinin-events].

Jaime, A., and Dasilva, T. (2003). Anthemideae: Advances in Tissue Culture, Genetics and Transgenic Biotechnology. African Journal of biotechnology. 2(12):547-566, 2003.

Kindscher, K. (1992). Medicinal wild plants of the prairie. An ethnobotanical guide. University press of Kansas. Pp340.

Klayman, D.L.(1993): Artemisia annua: From Weed to Respectable Antimalarial Plant. In: A.D. Kinghorn and M.F. Balandrin (eds.), Human Medicinal Agents from Plants. American Chemical Society. Symp. Series. Washington, DC. Pp: 242-255.

Lescano S.Z., Chieffi, P.P., Canhassi, R.R., Boulos, M. and Neto, V.A.(2004). Antischistosoma Activity of Artemather in Experimental Schistosoma mansoni: Revista de Saaaude Publica 38:71-75.

McVaugh, R. (1984). Compositae. Vol. 12. Flora NovoGaliciana: a Descriptive Account of the Vascular Plants of Western Mexico, ed. W.R. Anderson. University of Michigan Press, Ann Arbor. Med. 69: 289-299.

Muhammad Zia, Abdul-mannan And M. Fayyaz (2007). Effect of Growth Regulators and Amino Acids on artemisinin Production in the Callus of Artemisia absinthium Pakistan Journal of Botany. 39(2): 799-805.

Murashige T. and Skoog, F.(1962). ARrevised Medium for Rapid Growth and Bioassay with Tobacco Tissue Culture. Plant Physiologist. 15: 473-497.

NA. (2007). Mobilizing Science-Based Enterprises for Energy, Water, and Medicines in Nigeria,
National Research Council of the National Academies, National Academies Press, Washington, pp.45-54.

Pilloy, J. (2010). Artemisin Market Quantities and Pricing, A2S2-Assured Artemisinin Supply System, Artepal, Artemisin Conference, Madagascar, Oct., slide $16[$ www.mmv.org/newsroom/events/pastevent s/ past-artemisinin-events].

Paniego N.B. and Giulietti, A.M. (1994). Artemisia annua L.: Dedifferentiated and Differentiated cultures. Plant Cell Tiss. Org. Cult., 36:163-168.

RBM. (2009). Artemisinin Requirements for the Manufacture of ACTs. An Update on the Position Paper of the Procurement and Supply Chain Working Management Group, Tech. Paper, Nov. 27, Roll Back Malaria Partnership, World Health Organization, Geneva.

Razdan, M.K. (2002). Inroduction to plant Tissue Culture. Second Edition. Oxford \& IBH Publishing Co. Pvt. Ltd. New Delhi, India.pp375.

Sharma, V. P.(2006). Artemisinin Drugs in the Treatment of Plasmodium falciparum Malaria in India," Current Science (Bangalore) 90: 13231324.

Sugimoto, K., Gordon, S. P., and Meyerowitz, E. M.(2011). Regeneration in Plants and Animals: Dedifferentiation, Transdifferentiation, or Just Differentiation? Trends in Cell Biology, 21 (4): 212-218.

Tan, N.(2006). Global situation of Artemisia annua and artemisinin production. Meeting on the Production of Artemisinin and ArtemisininBased Combination Therapies, 6-7 June 2005, Arusha, United Republic of Tanzania, World Health Organization, Global Malaria Programme, Geneva.

Tripathi A.K., V. Projapati, K.K. Aggarwal, S.P. and Khanuja, S.K.(2000). Repellency and Toxicity of Oil from Artemesia annua to Certain Stored Product Beetles. Ecotoxicology 93:43-47.

Tripathi A.K., V. Projapati, K.K. and Aggarwal, S. K.(2001). Toxicity, Feeding Deterrence and Effect of Activity of 1,8-cineole from Artemisia annua on Progeny Production of Tribolium castaeum (coleopteran: Tenebrionidae). Journal of Economic Entomology: 94:979-983.

Ut, B.M. (2011). Aligning Artemisia and ACT Supplies. Vietnam Production Report 2011, Artemisinin Conf., Hanoi, Nov. 2 [http://www.mmv.org/newsroom/events/paste vents/ past-artemisinin-events].

Wiese AM, and Binning LK.(1987). Calculating the Threshold Temperature of Evelopment for Weeds. Weed Science 35,177-179.

Xiao S.H., B.A Catto.(1989). In vitro and In vivo Studies of the Effects of Artemether on Schistosoma mansoni. Antimicrobs Agents Chemother 33:1557-1562.

Xiao S.H., M.Booth, and Tanner, M.(2000):. The Prophylactic Effects of artemether Against Schistosoma japonicum infections.Parsitology Today 16:122-126. 